O. B. Chernega, Dr. Sc. (Econ.), Prof., orcid.org/0000-0002-8504-6299,

S. V. Voloshyna, Cand. Sc. (Econ.), Assoc. Prof., orcid.org/0000-0001-7148-6923,

L. D. Kostakova,

orcid.org/0000-0002-8720-0528
Donetsk National University of Economics and Trade named after Mykhayilo Tugan-Baranovsky, Kryvyi Rih, Ukraine, e-mail: chernega@donnuet.edu.ua; voloshyna@donnuet.edu. ua; kostakova@donnuet.edu.ua

\title{
PARADIGM OF MARGINAL ANALYSIS OF PROFITS OF ENTERPRISES WITH A MULTIPLE PRODUCTIVE PROCESS
}

Purpose. Development of a conceptual theoretical-analytical model of marginal analysis of profits for operating procedures of industrial enterprises with a multiple productive process and variety of operation profit conditioned by it.

Methodology. The theoretical and methodological background of the research involves the contemporary marginal theory and its independent area - the marginal analysis, which is based on the "cost - volume - profit" concept (breakeven concept) as well as on historical and system-activity based approaches related to implementation of the fundamental principles of the marginal analysis while managing costs and profits, general scientific and special methods (those of analysis, synthesis, abstraction, comparison, and generalization used to define the role of profits in management processes; studying the main approaches to the analysis of an enterprise's profits; drawing conclusions; theoretical and analytical modelling used to develop a model of the marginal analysis of profits, its formalization and specification of implementation conditions).

Findings. Management significance of business profits is revealed. Based on comparison of the basic approaches to the business unit profitability analysis, scientific voids of imperfection of marginal analysis methods were detected as well as the lack of the methods at enterprises with a multiple productive process. The developed production system scheme of an enterprise with a technology concept of business position and variety of the operation profits is taken as the basis of formation of the conceptual theoretical-analytical model of the marginal analysis. Conditions of promoting the marginal analysis among business units are determined. The theoretical model of the marginal analysis is formalized as industrial methodology, which is developed considering the specifics of activities of an iron ore mining and processing integrated plant. Classes of managerial decisions are defined, which can be implemented at enterprise structural units on the basis of the marginal analysis methodology.

Originality. It involves development of theoretical and methodological bases of the marginal analysis of profits based on developing the industrial methodology of conducting it at multiple production and elaboration of the new classes of managerial decisions for an enterprise's structural units.

Practical value. Applied relevance of the research results involves formalization of the conceptual theoretical-analytical model as industrial methodology of the marginal analysis of profits, which affords ground for a wider user community, including mining and processing integrated plants, to increase efficiency of managing costs and profits.

Keywords: profits, costs, marginal analysis, production system, stages (production area) of production, structural units, methodology, managerial decisions

Introduction. Research on profitability of national enterprises, their financial status in general has always held a prominent place among topical tasks of management at every economic level.

Practical problems in this subject area are evidenced in the data of the State Statistics Service of Ukraine. Thus, in 2017 the number of unprofitable enterprises in the country made $27.2 \%$ of their total number, which is higher than the level of this figure in 2016 and 2015 by 0.6 and $0.9 \%$, respectively. At the same time, the increase in the average level of efficiency of operating activities from $1 \%$ in 2015 to $8.9 \%$ in 2017 [1] occurred due to increasing demand in domestic and foreign markets and investment climate exhilaration in the country [2]. Sectoral analysis of the national business environment according to economic activities points to significant problems in providing profitability in the production sector, where percentage of unprofitable enterprises

(c) Chernega O. B., Voloshyna S. V., Kostakova L. D., 2018 in 2017 made $28.4 \%$, in construction $-28.6 \%$, in trade $-24.9 \%$, etc. [1]. The information presented allows claiming about long-term instability of financial results and a considerable number of unprofitable enterprises with its high level in the industry. Considering the raw-material nature of the national economy and the world primary commodity markets' coming "into one of the worst crises for the period since the Industrial Revolution of the $19^{\text {th }}$ century" [2], the issue of providing profitability of domestic enterprises remains in abeyance. Its solution will mostly depend on effect of the internal factors, which include methods and methodology of profit analysis as enterprise management instrumentation.

Under current conditions of economy management, methods of the marginal analysis, which are actively used in economically developed countries, are of interest for the national enterprise administration. This methodology is an instrument that includes relevant information for managing the scale of production, its costs 
and, finally, profits. Unlike traditional techniques and approaches to analyse profits, which are mostly applied by domestic enterprises, the method of the marginal analysis allows studying relations between key performance indices in greater detail and assessing the influence of the factors on costly characteristic and profitability of production more carefully.

Analysis of the recent research and publications. The contemporary paradigm of the marginal analysis has a long history and is associated with the names of such scientists as H.H. Gossen (1854, mathematic foundations of the theory of marginal utility), K. Menger, V. Jevons and L. Walras (the early 1870 s, research on the principles of diminishing marginal utility), W. Rautenstrauch (1930, the beginning of developing the breakeven conception), J.Garrison (1936, the concept of the system of direct-costing with cost division into variable and fixed),

D. Joel (1948, evaluation of the relevance of profits, price formation and expenditure monitoring based on breakeven graphs), and others [3].

Practical implementation of concepts of the marginal analysis fell on the second half of the $20^{\text {th }}$ century, which is related to intensification of scientific research in countries with developed market relations, whose prominent representatives are A.Apcherch, E.A.Atkinson, R.D. Banker, V. Govindaradjan, C. Drury, R. S. Kaplan, J.T.Sigel, K. K.Sio, J. Foster, P. Freedman, Ch. T. Horgner, J. Shank, J. K. Shim, and others.

In the post-Soviet space, M. G. Chumachenko was the first to study production breakeven. His work "Accounting and analysis in US industrial production" profoundly elucidates the essence of the marginal analysis and remains the fundamental one.

Domestic scientists contributed greatly to expanding the marginal analysis at the end of the $20^{\text {the }}$ and the beginning of the $21^{\text {st }}$ centuries; among them are P. Y.Atamas, I. A. Blank, F. F. Butynets, Yu. M. Velykyi, A. M. Gerasymov, S. F. Golov, M.H. Hreshchak, I. Ye. Davydovych, N. Yu. Ivanova, H. I. Kindratska, A. H. Zahorodnii, O. L. Mykhalska, S.Z. Moshenskyi, O. A. Orlov, V. I. Pazynych, H. O.Partyn, V.V.Prokhorova, M.S. Pushkar, E. H. Riasnykh, N. V.Sablina, H. V. Savytska, V. P. Savchuk, D.D.Surmai, A.V.Fedorkevych, Yu.S.TsalTsalko, A. V. Cherep, M. H. Chumachenko, and others.

Contemporary scientists have studied the issues of applying the marginal analysis to estimate profitability of certain types of products for forming its assortment $[4,5]$, defining breakeven sales volume and an enterprise safety zone [4-7], their factor scoring with the use of indices of variable and fixed costs and product prices, threshold levels of these indices [4-6], and others.

Many new argumentative issues of applying the marginal approach are being raised by scholars in the current decade. In their works, they emphasise the necessity of using the marginal analysis for assessing prices, costs and profits for individual production [5, 7], for evaluating efficiency of an enterprise's performance and improving its management $[4,8,9]$, for forecasting factors and results of management activities [9-11] and others. Moreover, recent publications draw attention to industrial peculiarities of applying the theory of the marginal analysis, namely, in engineering manufacture [9], transport [10] and so forth.

At the same time, certain aspects of the marginal analysis, in particular, such as its adaptedness to operational conditions of enterprises with a multiple productive process, have not been studied sufficiently, which conditions the unsolved scientific task to provide reliability of managing profits for these enterprises, which include powerful integrated plants of mining and metals.

Unsolved aspects of the problem. Analysis of the scientific achievements in this subject area has shown that the marginal analysis in its current form has certain restrictions to be applied at industrial enterprises, which include limited assortment of goods and steadiness of its structure. That is why at enterprises with a complex production system, which features multiple stages (in particular, in mining and metallurgy industries, chemical and petrochemical industries and others) a scientific void has developed regarding the lack of methodical instrument to make management decisions using the "cost-volume-profit" concept. Regarding this, we find it vital to transform the general methods of the marginal analysis into the industry-specific methods which consider specifics of work of industrial enterprises of technology concept specialisation and, respectively, with various results of economic activities.

Objectives of the article. The objective of the article is to develop a conceptual theoretical-analytical model of the marginal analysis of profits for operating procedures of industrial enterprises with a multiple productive process and variety of operation profit conditioned by it.

Methodology description. To achieve the set goal, the following tasks were to be solved successively:

- to reveal relation of profits to objectives of enterprise development and conditions of their achievement;

- to conduct the comparative analysis of the basic approaches to enterprise profit analysis with definition of their advantages, disadvantages, restrictions, prospects of further development;

- to develop a conceptual model of marginal analysis for enterprises with a multiple productive process and perform its formalisation as industry-specific methods for an iron ore mining and processing integrated plant;

- to determine possibilities of promoting the methods of the marginal analysis to an enterprise's structural units and define spheres of its implementation.

Presentation of the main research and explanation of scientific results. Any enterprise which operates in the market environment considers complete and timely satisfaction of social and individual needs as their main objective. Profit maximisation based on the optimization of volumes and resource structure acts as a criterion of achieving the objective. This postulate of the modern neoclassical economic theory, which originated as generalization of the market business practice, means that realization of consumer interests is possible mostly due to the manufacturer's economic interest in results of their performance. Realization of this interest is formulated through setting and achieving the enterprise's commercial purposes, among which the most topical 
ones are to secure profitable performance and provide conditions for its increase.

That is why it is considered that profits make the target of the enterprise's development, the source of its capital formation and satisfaction of intracompany and social needs and, as such, are the main estimated figures of business efficiency. Meanwhile, profit earning and increase in economic viability as a dual purpose of the economic development do not occur automatically, but on the basis of certain approaches to managing profits which are inclusively interrelated with functioning of other enterprise management subsystems (costs, sales, novation, prices and others). Moreover, the range of profit management tools and their integration with functioning tools of other enterprise management subsystems is constantly increased.

The main approaches to the profit analysis which are mostly spread worldwide are presented in Fig. 1.

Most domestic commodity producers apply traditional approaches to the profit analysis, which is related to historical traditions of guidelines on the part of state authorities. The traditional profit analysis is based on the set of interrelated methods, among which the main ones are the horizontal analysis (whose task is to study changes in the main indices of profits and profitability in time by setting generals trends), the vertical analysis (to study changes in the structure of formation, distribution and application of profits), the comparative analysis (to assess the enterprise's external position according to profitability level in the industry and among the main competitors), the factorial analysis (to evaluate the effect of factors which have functional and/or stochastic relation with profits) and others. Among the mentioned methods of the traditional analyses those are preferred which are based on functional relations between profits, physical sales volume, price and total production costs. When conducting the factorial analysis, the study is carried out on the basis of elimination, which allows distinguishing successively the effect of one factor while the others are conventionally regarded as invariable.

Under these conditions we have a relatively simple and time-proved tool of analytical study, which is spread at enterprises of various economic activities, different types of specialisation and with different results of eco-

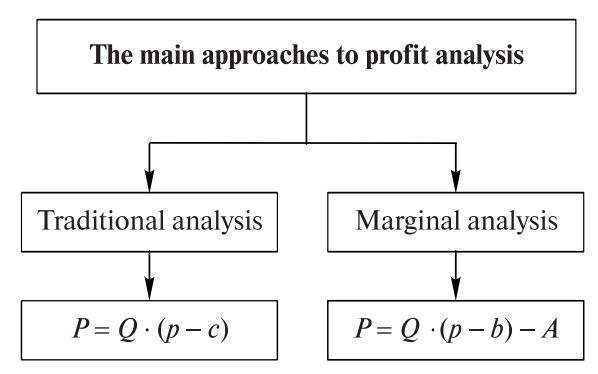

Fig. 1. Conceptual difference between the basic approaches to profit analysis:

$P$ - profits; $Q-$ physical volume of sales of products; $p-$ product price; $c$ - full production cost of a product unit; $b-$ variable costs on a product unit; $A$ - overall size of fixed costs nomic activities (one- and multiproduct). At the same time, the traditional methods of the profit analysis have insignificant disadvantages since taking into account the relation between profits, sales volume and general costs, they do not reflect peculiarities of costs behaviour and their sensitivity to change in the scale of activity.

The marginal analysis refers to modern tools of complex management of an enterprise proven by the world practice and, consequently, to a specific management analysis. It is also known as "cost-volume-profit" concept (system), CVP analysis, or breakeven concept [3-10]. It is based on studying the relation between the specified key performance indices and their flexible use for enabling profitability according to forecast development of the environment of an enterprise's functioning and an owner's targets.

Peculiarities of the CVP-analysis system are associated with the division of costs into variable and fixed ones and distinguishing of the so-called marginal profit (margin or coverage level). Moreover, the marginal analysis operates both with the general value of the marginal profits and its average quantity. In general, the marginal profit is a balance between sales proceeds and variable costs, which corresponds to the sum of fixed costs and profits in composition [3-10]. At the breakeven point, which is crucial for the business, the marginal profits will be equal to the fixed costs. At the same time, the sales proceeds and economic output are considered to be marginal; their size decrease results in losses. In turn, the economic substance of unit margin profit is in its ability to characterize the margin value, which an enterprise can obtain form manufacturing and selling a supplement production unit, which corresponds to its average size.

Therefore, presenting the scheme of calculating business profits using the marginal analysis (Fig. 1) does not contradict the marginalist theory, which envisages the frontier analysis of the key indices of the economic system, focusing managers' attention on the final result of their activities instead of traditional focus on general costs, taking into account performance conditions, which constantly change, using general, average and incremental amounts for this, and others [3-10]. Mentioned revolutionary changes in the economic practice, which the marginal theory brought, have made it possible to increase relevancy of managerial decisions regarding evaluation of terms for maximization of financial results of the performance (namely, the profits) and control of their threshold.

Let us also emphasize that within the benefits management, not only providing for as big part of profits as possible in the product price (margin coefficient) is important, but also for an operating leverage (relation between fixed and variable costs).

Modern methods for implementation of the margin analysis are geared to the conditions of one- and multiproduct manufacture and, apart from assessing the profit and profitability size, allow conducting the factorial analysis on the basis of functional relation between profits, sales volume, prices and variable and fixed costs structured according to the connection with the amount of business. Management value is attached to the given analysis by its ability to assess and forecast breakeven 
production volume as a limit of paying off constant expenses, the enterprise safety zone, range of products, price policy, to determine profits sensitivity to the change in the key factors, to model the behaviour of these factors to provide the target profit, and others.

However, application of the marginal analysis features certain restrictions. First of all, this is division of costs into variable and fixed costs, where the variable costs make a function of production volume, and the fixed costs do not change over a short-term period, while the production and sales volumes ate to be identical.

Therefore, understanding profits as a function of revenues and costs is common for the approaches distinguished in Fig. 1. However, substitution of full cost for variable and fixed costs in the marginal analysis changes its abilities in making managerial decisions. Thus, if identification of the factors which have conditioned the change in the enterprise's profits, then the marginal analysis shows the leverages which help to provide for both gaining the profits and their increase. This fundamental difference, on the one hand, conditions transition of an increasing number of enterprises to the use of the marginal analysis, and, on the other hand, puts forward new requirements for its range, which will allow more consumers to apply favourable and efficient methods.

Generalization of the characteristics of the methodical fundamentals of the basic approaches to the profit analysis is presented in Table 1.

Thus, methods of the marginal analysis compared to the traditional techniques of the analysis make it possible to study interrelations between the profits and a great number of factors, to evaluate their effect more precisely and so forth.

Development of the margin analysis under modern conditions proceeds towards the expansion of solving tasks which the enterprise faces when being considered as a production system with subject specialization. Under these conditions, most enterprises whose production systems are built based on the technology concept as well as structural units of these enterprises remain out of the scope of the marginal analysis techniques. This situation makes it impossible to make well-considered managerial decisions and creates a scientific void. To overcome it, first of all, it is necessary to fix attention on the model of an enterprise as a production system in which the results of economic activities are the function of spent resources, size and ratio of the latter ones. Functioning of the production system is provided as a result of efficient interaction of its composite elements (the subsystem of providing resources, subsystem of processing resources and obtaining production results, subsystem of management).

Apart from the subject and object of management, the management subsystem includes tools (methods) of management. Within this system, the marginal analysis as a separate type of the economic analysis acts as a potential element of the subsystem of managing an enterprise and its substructures and as a management function. Implementation of the latter is related to accumulating and processing information until it is appropriate for making managerial decisions.

Fig. 2 shows a model of a production system of an enterprise of technology concept-based specialisation presenting multiple connections which occur within production and management lines: from the object to the subject of management and in the opposite direction.

The enterprise's technology specialisation suggests division of the general production process into separate stages (process stages, steps, phases) which are to be passed by raw material to turn successively into the finished product. The results, which occur at different pro-

Table 1

Comparative analysis of methodical fundamentals of the basic approaches to the enterprise profit analysis

\begin{tabular}{|c|c|c|c|c|}
\hline \multirow{3}{*}{$\begin{array}{l}\text { Comparison } \\
\text { parameters }\end{array}$} & \multicolumn{4}{|c|}{ Approaches } \\
\hline & \multicolumn{2}{|c|}{ Traditional analysis } & \multicolumn{2}{|c|}{ Marginal analysis } \\
\hline & $\begin{array}{l}\text { One-product } \\
\text { manufacture }\end{array}$ & $\begin{array}{l}\text { Multi-product } \\
\text { manufacture }\end{array}$ & $\begin{array}{l}\text { One-product } \\
\text { manufacture }\end{array}$ & $\begin{array}{l}\text { Multi-product } \\
\text { manufacture }\end{array}$ \\
\hline Basic models & $P=Q \cdot(p-c)$ & $P=\sum_{i=1}^{n} Q_{\beta} \cdot D_{\beta} \cdot(p-c)$ & $P=Q \cdot(p-b)-A$ & $P=\sum_{3=1}^{i}\left[Q_{3} \cdot D_{3} \cdot\left(p_{3}-b_{3}\right)\right]-A$ \\
\hline $\begin{array}{l}\text { Additional symbols } \\
\text { in models }\end{array}$ & \multicolumn{4}{|c|}{$\begin{array}{l}n-\text { general number of product types of the set nomenclature; } i=1, \ldots, n-\text { restrictions on the number } \\
\text { of product types; } D_{i}-\text { ratio of the } \mathrm{i}^{\text {th }} \text { product type, fraction }\end{array}$} \\
\hline $\begin{array}{l}\text { System of managing } \\
\text { costs }\end{array}$ & \multicolumn{2}{|c|}{ "standard costing" } & \multicolumn{2}{|c|}{ "direct costing" } \\
\hline $\begin{array}{l}\text { The number of } \\
\text { important factors }\end{array}$ & 3 & 4 & 4 & 5 \\
\hline Advantages & \multicolumn{2}{|c|}{$\begin{array}{l}\text { simplicity of models, traditions of practical application, } \\
\text { possibility of application in any period of time }\end{array}$} & \multicolumn{2}{|c|}{$\begin{array}{l}\text { a tool of making managerial decisions on } \\
\text { profits, costs, assortment, prices and others }\end{array}$} \\
\hline Disadvantages & \multicolumn{2}{|c|}{$\begin{array}{l}\text { does not consider interrelation between profits and } \\
\text { behaviour of an enterprise's costs; is labour intensive }\end{array}$} & \multicolumn{2}{|c|}{$\begin{array}{l}\text { relative complexity of using; non-applicability } \\
\text { for long-term periods }\end{array}$} \\
\hline Use restrictions & \multicolumn{2}{|c|}{$\begin{array}{l}\text { labour intensity of application makes prompt } \\
\text { analysis and swift response impossible }\end{array}$} & \multicolumn{2}{|c|}{$\begin{array}{l}\text { complexity of dividing costs into variable and } \\
\text { fixed ones; identity of production volumes and } \\
\text { sales volumes; change in a range of products }\end{array}$} \\
\hline
\end{tabular}




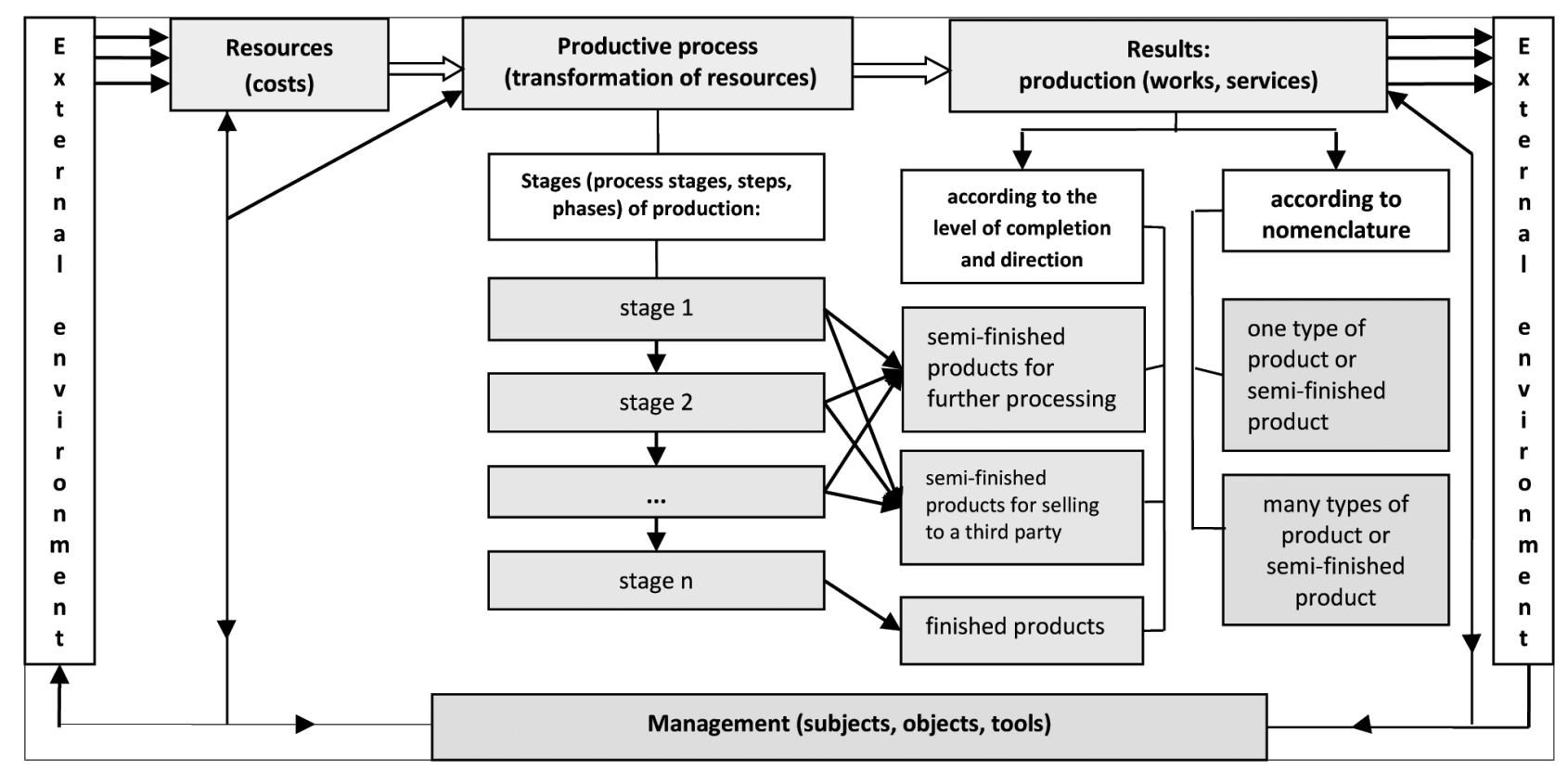

Fig. 2. The production system of an enterprise of technology concept-based specialization and variety of its results

duction stages, are expedient to structure according to the level of completion and direction as well as to product variety. Based on the first characteristic of division there are distinguished semi-finished products for further processing, semi-finished products for selling to a third party and finished products. Moreover, at every stage the result can occur both as one type and a few types of finished or semi-finished products. This variety of results with common participation of all structural units in developing finished products complicates both the organisation of production process and the processes of managing structural units.

Iron ore mining and processing integrated plants are an example of technologically specialised enterprises. Their main process stages include: 1 ) iron ore mining; 2) iron ore degradation; 3) iron-ore dressing; 4) iron ore agglomeration. According to the process stages, their activities result in ore mined, fine ore, concentrate, agglomerate (pellets). The eventual outcome (finished product) of the enterprise is the product derived at the last stage (concentrate, agglomerate or pellets). All the process stages are structured into sub-divisions, which are technologically and organisationally self-contained units, are considered to be responsibility centres and to which operational functions are delegated.

Under conditions of the worldwide recognition of the marginal analysis as a management accounting tool, which allows responding flexibly to changes in market and production situations, development of extensive information flows within the subdivisions and expediency of elaborating important managerial decisions by the "bottom-upwards" method, there occurs necessity of extension of techniques of the analysis under consideration to subdivisions.

The argumentation of such a conclusion resolves itself into consideration of peculiarities of the structural units' activities, namely:
1. The structural units are part of the enterprise and, therefore, objectives and tasks of its development are conveyed to the units, where there are actually achieved through creation of proper conditions and stimuli.

2. To accomplish tasks set, the structural units are endowed with operational independence, which is reflected in their ability to develop an operational strategy of the unit's development and participate in formation of the general strategy of the enterprise's development within the scope of their powers.

3. Officially having fewer risks in their activities, the structural units actually share their consequences, to which the enterprise is exposed (results in development budget reduction, downsizing, reduction in salaries and others).

4. The structural units have limited prospects to make managerial decisions (unconformity of methods which are applied by the enterprise and methods applied by the structural units with low realisation of the concept of participative management) and, as a result, a low level of the real effect on economic and production decisions which refer to the unit's activities.

Understanding the fact that solution of any issue requires a complex approach, we claim that transformation of the general methodology of the marginal analysis into the industrial methodology is to become one of the solutions on providing conditions for the enterprise's profitable work; the methodology would correspond to the specifics of the activities of an enterprise with a multiple productive process with defining tasks to be solved in the structural units.

Let us do the set scientific task for an iron ore mining and processing integrated plant's activities considering three process stages which are available at all enterprises of the similar specialization.

The conditions of implementation of the marginal analysis at the structural units of such an enterprise and, 
actually, of an enterprise with a multiple productive process in general will include:

1. Development of a "direct-costing" system at the enterprise with which production costs are strictly divided into variable and fixed costs. For such division, it is important to study changes in certain costs, which, in our opinion, should be done through application of methods of correlational and regression analyses.

2. Referring the costs of the preceding process stage to the following stage. That is to say, the cost of the product manufactured at a certain unit (at a process stage) will include expenses incurred by it and the costs to produce a semi-finished product at all the preceding process stages.

3. Considering the effect of industrial (natural) factors on cost formation (studied by the authors in [12]), which is reflected in necessity for individual planning of preparation expenses (to include expenses on pre-prospecting of deposits; expenses on area cleanup operations for an open-pit mining zone; expenses on fitting temporary access roads to move out excavated raw materials and others). These costs are assigned to the production cost portion-wise over the period of field development.

Table 2 presents the key performance indicators of the structural units of a mining and processing integrated plant which are obtained through the transformation of the general methods of the marginal analysis into the industrial methodology. These indicators should include profits, cost value and price.

The base formula to define profits, which is presented in Fig. 1, was changed depending on production process stage as a result of assigning costs of every next process stage to the product cost.

Determining the product (semi-finished product) cost by separate process stages proved the possibility to unify its formulas to the following structure

$$
c_{j}^{m}=b_{0}+\sum_{1}^{j} b_{j}^{m}+\sum_{1}^{j} \frac{A_{j}^{m}}{Q_{j}^{m}} .
$$

A formula to define the price of production (semifinished production) according to the process stages can be unified in the same way

$$
p_{j}^{m}=b_{0}+\sum_{1}^{j} b_{j}^{m}+\sum_{1}^{j} \frac{A_{j}^{m}}{Q_{j}^{m}}+\frac{P_{m}}{Q_{m}},
$$

under condition $P_{1}=P_{2}=\ldots=P_{m-1}=0$.

In general, the presented methodological approach to implementation of the marginal analysis allows not only giving an estimate to the performance of structural units according to the indices mentioned, but also participating in managing the enterprise realizing the following classes of managerial decisions:

1. Defining the critical (breakeven) production volume allows modelling the use of production capacities according to structural units and, at the same time, diagnosing issues with the enterprise's costly characteristic; solution of these issues belongs to the issues of the operational strategy of the enterprise subdivisions' development.

2. Making decisions on costs optimisation not only on the basis of assessment of budget performance by a subdivision, but also by analysing the coefficient of the production leverage. Increasing the level of this index at every process stage is an indicator of potentially large earnings growth at the enterprise in general. In case of derating of the coefficient of the production leverage, it is worth raising an issue of changes in the system of managing costs at a particular subdivision in order to optimise both the level and structure of costs.

Table 2

Key indicators of the industrial methodology of the marginal analysis for enterprises with a multiple productive

\begin{tabular}{|c|c|}
\hline $\begin{array}{l}\text { Stage (process } \\
\text { stage) }\end{array}$ & Performance indicator of a structural unit which provides responsibility at the process stage \\
\hline $\begin{array}{l}\text { Stage } 1 \text { (process } \\
\text { stage of iron ore } \\
\text { mining) }\end{array}$ & $\begin{array}{l}\text { 1. Variable costs at process stage } 1 \\
\qquad b_{1}=b_{0}+b_{1}^{m} \text {, } \\
\text { where } b_{0}, b_{1}^{m} \text { are preparation expenses and variable costs of the current period of process stage } 1 \text { on a } \\
\text { per-unit basis; } m \text { is a symbol which characterizes relation of information to the process stage which is } \\
\text { entered with a certain number; } j=1, \ldots, m \text { is limitation regarding the number of stages (process stages) of } \\
\text { the production process, where } b_{0}=\frac{C}{\sum_{t=1}^{T} Q_{t}} \text {, where } C \text { is the general size of one-time costs on preparation } \\
\text { works; } T \text { is the number of years of field exploitation (horizon workings); } Q_{t} \text { is the volume of ore mining in } \\
\text { the year } t \text {. } \\
\text { 2. Attributable profit at process stage } 1 \\
\qquad P_{1}=Q_{1} \cdot\left(p_{1}-b_{1}\right)-A_{1} . \\
\text { 3. Price of the semi-finished product (ore mined) at process stage } 1 \text {, which is obtained from formula (2) } \\
\text { and functions as the base price for selling to a third party } \\
\qquad p_{1}=b_{1}+\frac{P_{1}+A_{1}}{Q_{1}} .\end{array}$ \\
\hline
\end{tabular}
process (by the example of an iron ore mining and processing integrated plan) 


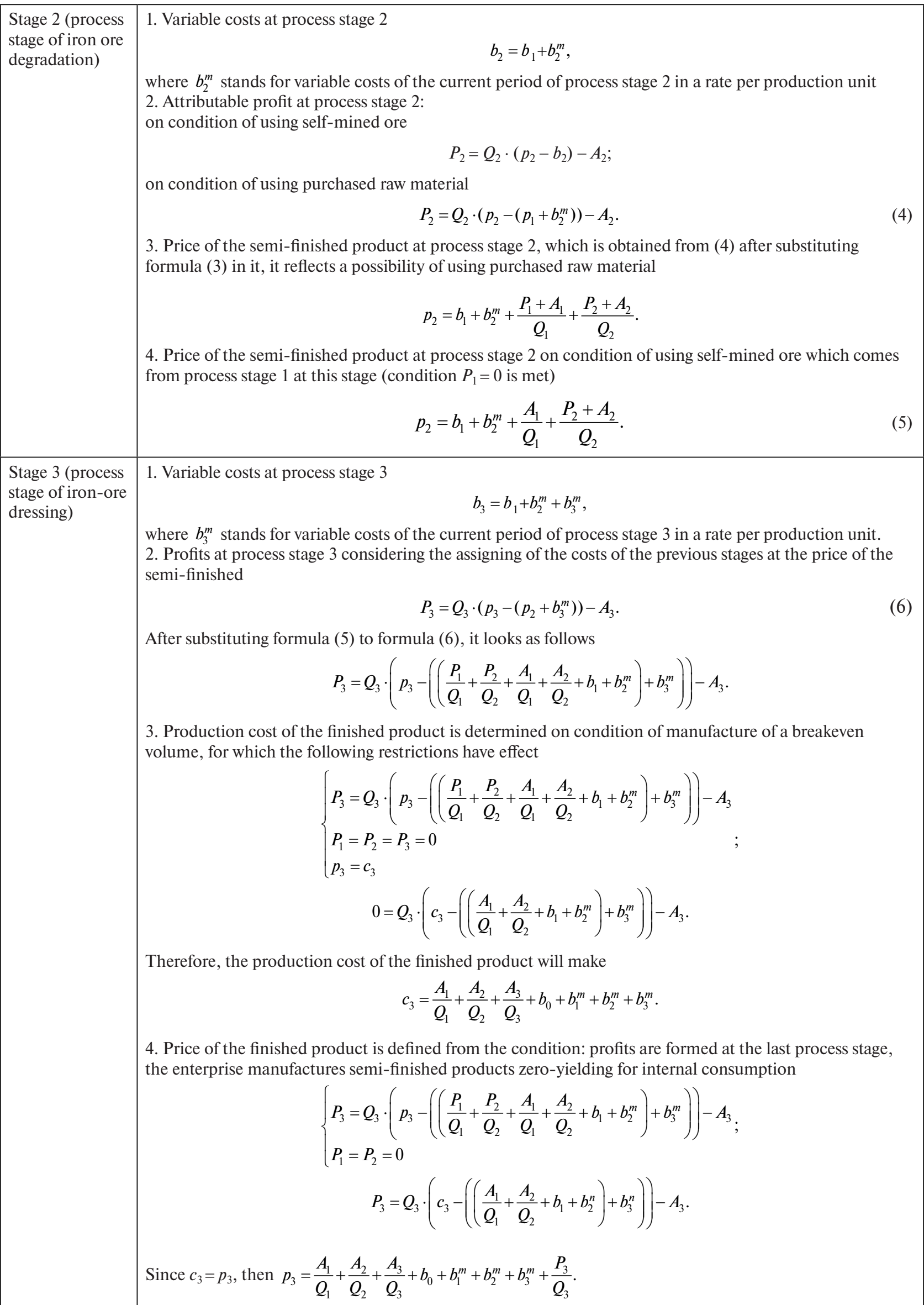


3. Defining the base price at a process stage is a reason for correcting the enterprise's price policy in terms of selling finished and semi-finished products.

4. Extension of internal economic relations at the enterprise on the basis of forming transfer prices which are developed on the common methodological basis with further changes in responsibility centres.

5. Pointing out the expediency of separating a production unit into a strategic economic unit with granting the right for the external market and others.

Conclusions and recommendations for further research. Research on the main approaches to the analysis of an enterprise has shown limitedness and imperfection of the methods which are used in practice by the domestic enterprises as well as lack of operational diagnostic methods for a considerable number of business entities; among them are enterprises with a multiple productive process. The theoretical-analytical model of the marginal analysis of profits, which has been developed for the stated economic sector, is presented in the conceptual form as a model of the production system of an enterprise of technological specialisation. A condition for efficient implementation of such a model is providing management entities with efficient methods of analysis, among which is the marginal analysis of profits, extension of structural units' powers as the basis of strengthening economic relations at the enterprise.

Formalisation of the theoretical-analytical model is performed by transformation of the general methodology of the marginal analysis into industrial methodology. It is determined that its implementation under conditions of technologically specialised enterprises' activities allows extending the structural units' participation in development of the operational strategy of their development and increase the circle of managerial decisions which can be made at the enterprise regarding operational and economic issues which refer to powers of these units.

The prospects of further research in the subject area of the marginal analysis implementation at enterprises with a multiple productive process are related to studying methodological approaches to substantiate making managerial decisions of different classes.

Participation in projects. The results of the research presented are obtained within a framework of the statefinanced scientific research on the subject "Social and economic aspects of development of enterprise economics" (state registration number 0115U005055), which was conducted according to the plan of scientific research of Donetsk National University of Economics and Trade named after Mykhayilo Tugan-Baranovsky.

\section{References.}

1. State Statistics Service of Ukraine [online]. Available at: <http://www.ukrstat.gov.ua> [Accessed 27 September 2017].

2. Overall results - 2017: Ukrainian industry, 2017 [online]. Available at: <https://mind.ua/publications/ 20180265-pidsumki-2017-ukrayinska-promislovist > [Accessed 09 December 2017].

3. Blaug, M., 2009. 100 great economists before Keynes. Translated from English, A. A. Fofonov, ed. [pdf]. Avail- able at: <http://www.library.fa.ru/files/Blaug-100.pdf> [Accessed 24 October 2017].

4. Surmai, D.D., Orlov, O.O. and Riasnykh, E.H., 2016. Marginal analysis of earnings growth reserves due to increasing volumes of selling production and decreasing production cost. Social-economic development of regions within international integration. Visnyk of Kherson National Technical University, 23(12), pp. 68-71.

5. Navaneetha, B., Punitha, K., Rashmi, M.J. and Aishwariyaa, T. Sai, 2017. An analysis of cost volume profit of Nestlé limited. International Journal of Commerce and Management Research, 3, pp. 66-68.

6. Drury, K., 2015. Management and cost account. Translation form English. Moscow:UNITI-DANA.

7. Orlov, O. O., 2015. Planning prices, costs and profits under conditions of single-unit production. Herald of Khmelnytskyi National University, 2(2), pp. 7-11.

8. Kostenko, O. M. and Kraievskyi, V. M., 2016. Marginal analysis in increasing efficiency of enterprises' performance and improving management of its level. Accounting and Finance, 3, pp. 148-152.

9. Myronova, Yu. Yu., 2016. Marginal approach to analysing production costs of machine engineering enterprises. Economics and Region, 3, pp. 132-140.

10. Fedorkevych, A. V., 2016. The role of the marginal analysis in managing transport organisations' performance. Ekononmichnyy analiz, 2(23), pp. 193-198.

11. Herasymovych, A. M. and Mykhalska, O.L., 2015. Marginal analysis in tactical management of an enterprise. Scientific Bulletin of National Academy of Statistics, accounting and Audit, 2, pp. 30-37.

12. Voloshyna, S. V. and Kostakova, L. D., 2017. Simulation analysis of relationship between production cost and natural environment of iron ore extraction and processing. Naukovyi Visnyk Natsionalnoho Hirnychoho Universytetu, 4, pp. 112-121.

\section{Парадигма маржинального аналізу прибутку підприємств із багатостадійним виробничим процесом}

\section{О. Б. Чернега, С. В. Волошина, Л. Д. Костакова}

Донецький національний університет економіки і торгівлі імені Михайла Туган-Барановського, м. Кривий Ріг, Україна, e-mail: chernega@donnuet.edu.ua; voloshyna@ donnuet.edu.ua; kostakova@ donnuet.edu.ua

Мета. Розробка концептуальної теоретико-аналітичної моделі маржинального аналізу прибутку для умов функціонування промислових підприємств із багатостадійним виробничим процесом i обумовленим ним різноманіттям результатів господарської діяльності.

Методика. Теоретико-методологічною основою дослідження виступає сучасна маржинальна теорія та іiї самостійний напрям - маржинальний аналіз, що базується на концепції „витрати - обсяг - прибуток“ (концепції беззбитковості), а також історичний і системно-діяльнісний підходи, пов'язані з реалізацією основних положень маржинального аналізу в управлінні витратами й прибутком. Також застосовані загальнонаукові та спеціальні методи: 
аналізу, синтезу, абстрагування, порівняння, узагальнення - для визначення ролі прибутку в управлінському процесі, вивчення основних підходів до аналізу прибутку підприємства; теоретико-аналітичного моделювання - для розробки моделі маржинального аналізу прибутку, іiї формалізації та деталізації умов реалізаціі.

Результати. Розкрита управлінська значущість прибутку підприємства. На основі порівняння базових підходів до аналізу прибутку підприємства діагностовано існування наукової прогалини недосконалості методик маржинального аналізу та їх відсутність для підприємств із багатостадійним виробничим процесом. За базу формування концептуальної теоретико-аналітичної моделі маржинального аналізу прийнято розроблену схему виробничої системи підприємства із технологічним принципом спеціалізації та різноманіттям результатів господарської діяльності. Визначені умови поширення маржинального аналізу у структурні підрозділи підприємства. Теоретичну модель маржинального аналізу формалізовано у вигляді галузевої методики, що розроблена з урахуванням специфіки діяльності гірничо-збагачувального комбінату з видобування залізних руд. Визначені класи управлінських рішень, що можуть бути реалізовані у структурних підрозділах підприємства на основі методики маржинального аналізу.

Наукова новизна. Полягає в розвитку теоретичних i методичних засад маржинального аналізу прибутку на основі створення галузевої методики його проведення для умов багатостадійного виробництва та опрацювання нових класів управлінських рішень для структурних підрозділів підприємства.

Практична значимість. Прикладне значення результатів дослідження полягає у формалізації концептуальної теоретико-аналітичної моделі у вигляді галузевої методики маржинального аналізу прибутку, що надає можливості розширеному колу користувачів, серед яких гірничо-збагачувальні комбінати, підвищити ефективність управління витратами й прибутком.

Ключові слова: прибуток, витрати, маржинальний аналіз, виробнича система, стадії (переділи) виробництва, управлінські рішення

\section{Парадигма маржинального анализа прибыли предприятий с многостадийным производственным процессом}

\section{О. Б. Чернега, С. В. Волошина, Л. Д. Костакова}

Донецкий национальный университет экономики и торговки имени Михаила Туган-Барановского, г. Кривой Рог, Украина, e-mail: chernega@donnuet.edu.ua; voloshyna@ donnuet.edu.ua; kostakova@ donnuet.edu.ua

Цель. Разработка концептуальной теоретикоаналитической модели маржинального анализа прибыли для условий функционирования промышленных предприятий с многостадийным производственным процессом и обусловленным им многообразием результатов хозяйственной деятельности.
Методика. Теоретико-методологической основой исследования выступает современная маржинальная теория и ее самостоятельное направление - маржинальный анализ, основанный на концепции „затраты - объем - прибыль“ (концепции безубыточности), а также исторический и системно-деятельностный подходы, связанные с реализацией основных положений маржинального анализа в управлении затратами и прибылью. Также применены общенаучные и специальные методы: анализа, синтеза, абстрагирования, сравнения, обобщения - для определения роли прибыли в управленческом процессе, изучения основных подходов к анализу прибыли предприятия; теоретико-аналитического моделирования - для разработки модели маржинального анализа прибыли, ее формализации и детализации условий реализации.

Результаты. Раскрыта управленческая значимость прибыли предприятия. На основе сравнения базовых подходов к анализу прибыли предприятия диагностировано наличие научного пробела относительно несовершенства методик маржинального анализа и их отсутствие для предприятий с многостадийным производственным процессом. За основу формирования концептуальной теоретикоаналитической модели маржинального анализа была принята разработанная схема производственной системы предприятия с технологическим принципом специализации и многообразием результатов хозяйственной деятельности. Определены условия распространения маржинального анализа в структурные подразделения предприятия. Теоретическая модель маржинального анализа формализована в виде отраслевой методики, разработанной с учетом специфики деятельности горнообогатительного комбината по добыче железных руд. Определены классы управленческих решений, которые могут быть реализованы в структурных подразделениях предприятия на основе методики маржинального анализа.

Научная новизна. Состоит в развитии теоретических и методических основ маржинального анализа прибыли на основе создания отраслевой методики его проведения для условий многостадийного производства и разработки новых классов управленческих решений для структурных подразделений предприятия.

Практическая значимость. Прикладное значение результатов исследования заключается в формализации концептуальной теоретико-аналитической модели в виде отраслевой методики маржинального анализа прибыли, что дает возможность расширенному кругу пользователей, среди которых горно-обогатительные комбинаты, повысить эффективность управления затратами и прибылью.

Ключевые слова: прибыль, затраты, маржинальный анализ, производственная система, стадии (переделы) производства, управленческие решения

Рекомендовано до публікації докт. екон. наук Г. О. Горіною. Дата надходження рукопису 03.11.17. 